\title{
MAF wt Allele
}

National Cancer Institute

\section{Source}

National Cancer Institute. MAF wt Allele. NCI Thesaurus. Code C53034.

Human MAF wild-type allele is located within $16 q 22-q 23$ and is approximately $6 \mathrm{~kb}$ in length. This allele, which encodes transcription factor MAF protein, is involved in the modulation of transcription by RNA polymerase II. 